\title{
Consideraciones sobre la comunicación científica en la era hiperconectada post COVID-19
}

\section{Considerations on scientific communication in the hyperconnected post COVID-I9}

\author{
José Luis Vázquez
}

Las circunstancias del mundo actual provocan reflexiones polifacéticas sobre la ciencia desde diferentes puntos de vista, correspondientes a la complejidad de la realidad. Es patente la relevancia de la investigación científica para enfrentar amenazas como la COVID-19. Gracias a la ciencia, pronto, las vacunas desarrolladas en un tiempo récord serán fundamentales en nuestro camino para salir de la pandemia. Una vez más, la humanidad demuestra que los desafíos globales exigen la cooperación de todos. La ciencia es el esfuerzo colectivo sumo, y sus beneficiosos resultados nos ayudan a generar soluciones para la vida cotidiana y responder a los grandes misterios del universo.

Mucha gente utiliza innovaciones que provienen de la ciencia sin conocer el titánico desarrollo que hay detrás. Los logros científicos son el resultado aplicado de un proceso largo y complicado que tiene como núcleo la comunicación. Como neuronas en las masivas redes del cerebro u otras células del cuerpo, los científicos, investigadores y otros actores relevantes analizan, comparten e intercambian conocimientos e información para seguir avanzando, siempre buscando medios para comunicarse entre sí.

Como cajas de resonancia que amplifican la difusión de los hallazgos científicos, las revistas académicas juegan un papel indispensable en los procesos de comunicación del mundo de la ciencia, mientras enfrentan obstáculos como la barrera del idioma, el acceso a la información y los costos. En las circunstancias mundiales de estrés e incertidumbre debido a la pandemia de COVID-19, los científicos compartieron datos, hallazgos y conocimientos. Sin mecanismos rápidos de comunicación y colaboración, donde las revistas académicas son primordiales, todo habría sido diferente.

Los resultados de la investigación pueden proporcionar los componentes esenciales para abordar un pro-
Current world circumstances provoke multifaceted reflections on science from different standpoints correspondent to the complexity of reality. The relevance of scientific research to face threats such as COVID-19 is clear. Thanks to science, soon, the vaccines developed in record time will be instrumental on our way out of the pandemic. Once again, humanity demonstrates that global challenges demand everyone's cooperation. Science is the ultimate collective endeavor, and its beneficial results help us generate solutions for everyday life and answer the great mysteries of the universe.

Many people use innovations that originate from science without knowing the titanic development behind them. Scientific achievements are the applied result of a complicated and lengthy process where communication is the core. Like neurons in the brain's massive networks or other body cells, scientists, researchers, and other relevant actors analyze, share and exchange knowledge and information to keep moving forward, always looking for ways to communicate with each other.

As soundboards that amplify the dissemination of scientific findings, academic journals play a crucial in the communication processes of the world of science, while confronting obstacles like language barriers, access to information and costs. In the global circumstances of stress and uncertainty due to the COVID-19 pandemic, scientists shared data, findings, and knowledge. Without rapid communication and collaboration mechanisms, where academic journals are paramount, everything would have been different.

Research results can provide the essential components to address a problem from a social and health sciences implementation perspective. Monitoring phenomena, such as COVID-19 cases, is possible thanks to scientific research, which is why governments, agencies

\footnotetext{
Correspondencia:

José Luis Vázquez

Correo electrónico: sinadiccion@gmail.com

doi: 10.28931/riiad.2021.1.01
} 
blema desde una perspectiva de implementación de las ciencias sociales y de la salud. El monitoreo de fenómenos, como los casos de COVID-19, es posible gracias a la investigación científica, por lo que gobiernos, agencias e instituciones han estado buscando respuestas en la investigación científica. Aunque los datos eran escasos al comienzo de la pandemia, hoy contamos con una abrumadora cantidad de estudios que intentan resolver la crisis y hacer que "regresemos a la normalidad" Io antes posible.

Debido al vacío inicial de información, la gente llenó los huecos con especulaciones, simplificación excesiva e incluso hechos engañosos o falsos. Este mismo fenómeno sucede en diferentes áreas del conocimiento donde aún es necesario desarrollar más investigaciones. Tal es el caso del campo de las sustancias psicoactivas, donde el número de estudios sigue siendo limitado y todavía queda mucho por descubrir, sobre todo en realidades distintas a la de América del Norte.

La investigación científica actual ha demostrado que, en todo el mundo (Degenhardt et al., 2018), los trastornos por uso de sustancias imponen una pesada carga de enfermedad, discapacidad y muerte, lo que representa años de vida saludable perdidos, disminución de la productividad y el bienestar, y altos costos sociales, entre otros problemas (Forouzanfar et al., 2015). Además, desde una perspectiva de género, las investigaciones señalan que las mujeres desarrollan trastornos por consumo de sustancias más rápido que los hombres (Hernandez-Avila et al., 2004), enfrentan más desafíos de adherencia y acceso al tratamiento, y están sujetas a un fuerte estigma.

La pandemia de COVID-19 sorprendió a los sistemas de salud y planteó graves dificultades para responder a la crisis, lo que reveló situaciones problemáticas como la inequidad y la profundización de la desigualdad. Quienes consumen drogas tienen un mayor riesgo de contraer la enfermedad (Hiller-Sturmhoefel, 2021). Las condiciones de vulnerabilidad y desventaja social agravan este riesgo para poblaciones como las personas en situación de calle, quienes experimentan alta comorbilidad, falta de adherencia al tratamiento y mayor tasa de mortalidad (Baggett et al., 2013).

Las condiciones impuestas por la COVID-19 intensificaron la compleja situación que enfrentan los servicios de salud y los centros de tratamiento para personas con trastornos por uso de sustancias. Los países han implementado acciones como confinar a la población en sus hogares o albergues por periodos prolongados para controlarla. En algunos casos, los servicios de salud han interrumpido o incluso suspendido sus labores, lo que es especialmente duro para las Américas. En esta región, los trastornos mentales, neurológicos y por uso de sus- and institutions have been looking for answers in scientific study. Although data was scarce at the beginning of the pandemic, today, we have an overwhelming number of studies trying to solve the crisis and "return to normal" as soon as possible.

Due to the initial lack of information, people filled the gaps with speculation, oversimplification and misleading or even false facts. This same phenomenon occurs in different areas of knowledge where it is still necessary to develop more research. Such is the case of psychoactive substances field, where the number of studies remains limited, and there is still much to be discovered, especially in realities which are different from North America.

Current scientific research has shown that, worldwide (Degenhardt et al., 2018), substance use disorders impose a heavy burden of disease, disability, and death, representing years of healthy life lost, decreased productivity and well-being, and high social costs, among other problems (Forouzanfar et al., 2015). Furthermore, from a gender perspective, research indicates that women develop substance use disorders faster than men (Hernandez-Avila et al., 2004), face more adherence and access to treatment challenges, and are subject to strong stigma.

The COVID-19 pandemic surprised health systems and posed serious difficulties in responding to the crisis, revealing problematic situations such as inequity and deepening inequality. Those who use drugs have a higher risk of contracting the disease (Hiller-Sturmhoefel, 2021). Conditions of vulnerability and social disadvantage exacerbate this risk for populations such as people in street situations, who experience high comorbidity, lack of adherence to treatment and higher mortality rates (Baggett et al., 2013).

The conditions imposed by COVID-19 intensified the complex situation faced by health services and treatment centers for people with substance use disorders. Governments of different countries have implemented actions such as confining the population to their homes or shelters for prolonged periods to control it. In some cases, health services have interrupted or even suspended their work, which is especially hard for the Americas. In this region, mental, neurological, and substance use disorders account for a significant proportion of health problems, and among people with these problems, disability and mortality rates are higher.

Treatment systems and services can ease the strain that drug use disorders inflict on countries. Providing care for people facing drug use disorders places a great responsibility on public health systems. Almost 1 in 10 people have a mental health disorder, but only $1 \%$ of global h-ealth personnel can provide the necessary care (World Health Organization [WHO], 2016). Nevertheless, the potential benefits would be for the af- 
tancias corresponden a una proporción significativa de los problemas de salud, y entre las personas con estos problemas, las tasas de discapacidad y mortalidad son más altas.

Los sistemas y servicios de tratamiento pueden aliviar la tensión que los trastornos por consumo de drogas infligen en los países. Brindar atención a las personas que enfrentan trastornos por consumo de drogas impone una gran responsabilidad a los sistemas de salud pública. Casi 1 de cada 10 personas presenta un trastorno de salud mental, pero sólo 1\% del personal sanitario mundial puede brindar la atención necesaria (World Health Organization [WHO], 2016). Sin embargo, los beneficios potenciales serían para las personas afectadas, sus familias, su comunidad y la sociedad.

Lenta pero constantemente, varios equipos de investigación han documentado los efectos de la COVID-19 más allá de la salud física. Ahora sabemos más sobre el impacto de la pandemia en la salud mental, la sociedad y el bienestar. Acompañadas por el coronavirus y las medidas para contener su propagación, algunas características del contexto, que se han moldeado desde hace mucho tiempo, se han exacerbado. El confinamiento forzó una transición repentina de las actividades presenciales hacia el mundo virtual. La conexión a Internet se volvió indispensable para mantenerse en contacto con familiares y amigos, asistir a clases, aprender cosas nuevas, trabajar desde casa, recibir las últimas noticias e involucrarse en actividades culturales, recreativas y de ocio.

A pesar de su papel trascendental, las personas tienen un acceso desigual a las tecnologías de la información y la comunicación (TIC). El brote de COVID-19 ocurre cuando más de la mitad de la población mundial tiene acceso limitado o nulo a Internet. La falta de preparación para adaptarse a las versiones online de socialización, aprendizaje y atención médica, entre otras actividades, puede provocar alteraciones en la población, como el tecnoestrés. En este escenario, necesitamos información precisa para producir respuestas adecuadas a corto plazo y planificar los pasos futuros para abordar las dramáticas consecuencias de la pandemia, como el aumento sin precedentes de los niveles de pobreza (Economic Commission for Latin America and the Caribbean [ECLAC], 2021). Compartir conocimientos, colaborar para generar ideas innovadoras y dar forma a nuevas líneas de investigación son los principales componentes que contribuirán a la consecución de estos objetivos.

La investigación nos permite comprender el desarrollo de eventos como la pandemia y prepararnos para el futuro. El ingrediente principal de este proceso es el conocimiento, que debemos incluir en los platos vanguardistas de nuestros menús. Al igual que ocurre con las especias más preciadas, el conocimiento necesita fected people, their families, their community, and the society.

Slowly but steadily, several research teams have documented the effects of COVID-19 beyond physical health. Now we know more about the pandemic's impact on mental health, society and well-being. Accompanied by the coronavirus and the measures to contain its spread, some characteristics of the context, shaped long ago, have been exacerbated. Lockdown forced a sudden transition from in-person activities to the virtual world. The Internet connection became essential to stay in touch with family and friends, attend classes, learn new things, work from home, receive the latest news, and get involved in cultural, recreational, and leisure activities.

Despite their vital role, people have unequal access to information and communication technologies (ICT). The COVID-19 outbreak occurs when more than half the worldwide population has limited or no access to the Internet. The lack of preparation to adapt to the online versions of socialization, learning and medical care, among other activities, can cause alterations in the population, such as technostress. In this scenario, we need accurate information to produce adequate short-term responses and plan future steps to address the pandemic's dramatic consequences, like the unprecedented rise in poverty levels (Economic Commission for Latin America and the Caribbean [ECLAC], 2021). Sharing knowledge, collaborating to generate innovative ideas, and shaping new research lines are the main components that will contribute to the achievement of these objectives.

Research allows us to understand the development of events like the pandemic and prepare for the future. The main ingredient in this process is knowledge, which we must include in our menus' avant-garde dishes. As with the most precious spices, knowledge requires special containers that allow long-distance transportation while preserving their freshness and properties. Nowadays, academic journals are suitable for this work, which demands expedite knowledge share and rapid collaboration within the scientific community in charge of addressing modern problems of our reality, with the aim of delivering the results to the table of everybody.

We must continue striving towards fully developing knowledge, using the most valuable scientific communication and dissemination tools. Journals like Revista Internacional de Investigación en Adicciones (RIIAD) are our source of inspiration and answers to the threats we face, which deserve further study.

As part of the extensive body of specialized publications from the Americas indexed in different international scientific databases, RIIAD will continue expanding knowledge in the region, with a massive impact due to its popularity and accessibility, driven mainly by its open 
recipientes especiales que permitan el transporte de larga distancia y conserven su frescura y propiedades. Hoy en día, las revistas académicas son aptas para esta labor, que exige acelerar el intercambio de conocimientos y una rápida colaboración dentro de la comunidad científica encargada de abordar los problemas modernos de nuestra realidad, con el objetivo de entregar los resultados en la mesa de todos.

Debemos seguir esforzándonos por desarrollar plenamente el conocimiento, utilizando las herramientas de comunicación y divulgación científica más valiosas. Publicaciones como la Revista Internacional de Investigación en Adicciones (RIIAD) son nuestra fuente de inspiración y respuestas ante las amenazas a las que nos enfrentamos, las cuales merecen un mayor estudio.

Como parte del extenso cuerpo de publicaciones especializadas de las Américas, indexadas en diferentes bases de datos científicas internacionales, RIIAD continuará expandiendo el conocimiento en la región con un impacto masivo debido a su popularidad y accesibilidad, impulsada principalmente por sus características editoriales de acceso abierto. Desde el punto de vista regional, continuaremos beneficiándonos de las publicaciones de la RIIAD como referentes de evidencia científica en el proceso de toma de decisiones.

\section{REFERENCIAS}

Baggett, T. P., Hwang, S. W., O'Connell, J. J., Porneala, B. C., Stringfellow, E. J., Orav, E. J., Singer, D., E. \& Rigotti, N. A. (2013). Mortality among homeless adults in Boston shifts in causes of death over a 15-year period. JAMA Internal Medicine, 173(3), 189-195. doi: 10.1001/jamainternmed.2013.1604

Degenhardt, L., Charlson, F., Ferrari, A., Santomauro, D., Erskine, H., Mantilla-Herrara, A., Whiteford, H., Leung, J., Naghavi, M., Griswold, M., Rehm, J., Hall, W., Sartorius, B., Scott, J., Vollset, S. E., Knudsen, A. K., Haro, J. M., Patton, G., Kopec, J., Malta, D. C. ... Rehm, J. (2018). The global burden of disease attributable to alcohol and drug use in 195 countries and territories, 1990-2016: a systematic analysis for the Global Burden of Disease Study 2016. The Lancet Psychiatry, 5(12), 987-1012. doi: 10.1016/s22150366(18)30337-7

Economic Commission for Latin America and the Caribbean. (2021). Social Panorama of Latin America 2020. https://www.cepal.org/ en/publications/46688-social-panorama-latin-america-2020

Forouzanfar, M. H., Alexander, L., Anderson, H. R., Bachman, V. F., Biryukov, S., Brauer, M., Burnett, R., Casey, R., Coates, M. M., Cohen, A., Delwiche, K., Estep, K., Frostad, J. J., KC, A., access editorial characteristics. From the regional standpoint, we will continue to benefit from RIIAD publications as references of scientific evidence in the decision-making process.

Kyu, H. H., Moradi-Lakeh, M., Ng, M., Slepak, E. L., Thomas, B. A. ... Murray, C. J. (2015). Global, regional, and national comparative risk assessment of 79 behavioural, environmental and occupational, and metabolic risks or clusters of risks in 188 countries, 1990-2013: a systematic analysis for the Global Burden of Disease Study 2013. The Lancet, 386(10010), 22872323. doi: 10.1016/S0140-6736(15)00128-2

Hernandez-Avila, C. A., Rounsaville, B. J., \& Kranzler, H. R. (2004). Opioid, cannabis and alcohol-dependent women show more rapid progression to substance abuse treatment. Drug and Alcohol Dependence, 74(3), 265-272. doi: 10.1016/j. drugalcdep.2004.02.001

Hiller-Sturmhoefel, S. (13 de enero de 2021). People with SUDs have increased risk for COVID-19 and worse outcomes. NIDA Notes. https://www.drugabuse.gov/news-events/nidanotes/2021/01/people-with-suds-have-increased-risk-forcovid-19-worse-outcomes

World Health Organization. (2016). mhGAP intervention guide for mental, neurological and substance use disorders in nonspecialized health settings: mental health Gap Action Programme (-mhGAP) - version 2.0. https://www.who.int/publications/i/item/ mhgap-intervention-guide---version-2.0 